\title{
Planning and Economics
}

$\mathrm{A}^{\mathrm{T}}$

$\mathrm{T}$ the recent Aberdeen meeting of the British Association, several interesting papers were contributed to a discussion on "Economic Planning" arranged by Section F (Economic Science and Statistics). In opening the discussion, Prof. D. H. Macgregor, of Oxford, said that the problem to be considered is the case of private enterprise versus the control of private enterprise. While it is admitted that mistakes and waste occur under private enterprise, yet under planning any mistake that is made would be much more serious and might involve very great losses and waste. From an examination of the records in Somerset House of joint stock companies, it has been found that 60 per cent of the companies formed over a certain period were dead in ten years, that less than 30 per cent survived twenty years and only 18 per cent survived for 40 years. This is a high mortality and indicates the risks involved. In money, the wastage amounts to about forty-four million sterling a year or one or two per cent of the national income of England and Wales at the time. A sixth of the year's savings was offset by the dead loss involved. These figures indicate that, under planning, the risk of loss which would result from serious mistakes is very great indeed.

Deprecating dramatic talk about a new order of things, Prof. Macgregor held that what is really required is to work our way gradually into a higher and better organisation of competitive industry such as would have worked itself out if the War had not taken place. There has been much talk about President Roosevelt's "New Deal", but it should be remembered that in Britain we dealt these cards long ago. For example, the Trade Board legislation dates back to 1909 and our social insurance scheme to 1911 . America is not so much giving a new deal as dealing in a hurry.

Sir Josiah Stamp, who followed, stated that he felt that the change now going on is rather greater than Prof. Macgregor was prepared to admit. There is, he said, an instinctive feeling at the present time among many persons that unco-ordinated individualism has given rise to maladjustments, since under it every individual conducts his business entirely within the limits of his own estimations of the market, with resultant mistakes. When we have all these individual business judgments being made, the total supply forthcoming is practically accidental. The con. sequence of mistaken judgments has now become too serious for others to put up with it lightly. Therefore we are told that it is impossible to go back to the muddle of individualism. On the other hand, the technique of planning is likely also to lead to a muddle, and the question is, which muddle are we going to deal in ? Most persons to-day would seem to hanker after the middle line between unrestricted individualism and complete national plan. ning. He agreed with Prof. Macgregor that if we do plan and make mistakes, then we shall be faced with something worse than we had under individualism. A solution cannot be found by imposing fixed prices on the community, since the more this is attempted, the more likely we should be to have the reactions which were prevalent during the War period. The possibilities of making profits must be there, for we cannot revive industries by sitting on the mainspring. If there were no profits-whatever form these may take-the industry would have to be subsidised by the community and would become merely parasitic.

Prof. W. F. Bruck, formerly of the University of Münster, maintained that planned systems which aim at excluding the market, with its free play between private undertakings, in favour of the State as leader of the national economy, exist only in theory. Even in Russia, such domination of the economic sphere is limited in the home market by capitalist methods and in the world market by the price mechanism of the liberal economy. However complete the socialist planned economy may be, it cannot eliminate risk; it can only transfer it from private enterprise to the State. The forces of economic life, like the forces of Nature themselves, can only be influenced, not absolutely controlled. Complete abolition of the market is impossible and any attempt to submit the complex organisation of modern trade to regimental discipline is hazardous. These obstacles and our present incomplete knowledge of them will compel those who strive to exclude the market from their planned economies to re-invent the market that they have eliminated. To-day, no State shows either a perfect liberal economy or a perfect planned economy, but all show invasions in the economic sphere. The economy of our States is a mixture of both capitalism and socialism, and they only differ in the degree of the intensity of this mixture, ranging from present-day England through America, Germany and Italy to Russia. In advocating the formation of industrial units similar to the German 'mixed enterprises', which provide a compromise between public and private control, Prof. Bruck suggested that whole trades might be controlled in this way either in groups, cartels or co-operative societies. The 'mixed enterprise' combines the advantages of private organisation, which avoids red tape and politics, with those of State participation, which ensures proper consideration of the interests of the community.

Prof. A. Gray, of the University of Aberdeen, said that while he is not necessarily opposed to planning, it is difficult to know what exactly it is all about. Let us admit, he said, that planning may in certain cases bring health to an industry by the elimination of useless units and by the rationing of supply at such a level as would enable a profitable price to be exacted. But does this bring us any nearer to the ultimate solution of the problem? It may merely result in placing the members of a particular industry in an advantageous position. There might be 'cut. throat' competition between different industries just as much as between different units in the same industry. Most industries are competing against each other for the favour of the consumer. Short of making people consume according to plan, nothing would prevent changes of tastes and desires ; men are in. consistent ever and women are a great deal more. One element of uncertainty in long-distance planning is the possibility of variation with regard to population. Thus the United States appears to be approaching a stationary stage and in many respects they have built for a larger population than they are likely to achieve. If the State be the planner, it must have a population policy. A planned State demands planning, not merely in industry, but also in all the diverse elements of national life. 